\title{
Trends in body mass index values of Brazilian enlisted men, 1980 to 2005
}

\author{
César Marra $^{1,2 \star}$, Flávia dos Santos Barbosa ${ }^{1}$ and Rosely Sichieri ${ }^{1}$ \\ ${ }^{1}$ Department of Epidemiology, Institute of Social Medicine, State University of Rio de Janeiro, Rio de Janeiro, RJ, Brazil. \\ ${ }^{2}$ Brazilian Army Physical Fitness Research Institute, Rio de Janeiro, RJ, Brazil.
}

Accepted 18 October, 2012

\begin{abstract}
This study was to investigate the temporal evolution of body mass index (BMI) in young enlisted men of 18 years in Brazil between 1980 and 2005, to identify specific points of greatest variance in time series and compare specific points in time, and the temporal evolution of BMI with socioeconomic changes in Brazil. The present study explores a temporal series of twenty-six national surveys of Brazilian men enlisted between 1980 and 2005. Heteroscedasticity in BMI time series was tested using Engle's Lagrange-multiplier (LM) test, and analyses were performed using the autoregressive conditional heteroscedasticity (ARCH) model. As possible explanations for these increases in mean BMI, changes in economic indicators were considered. Particularly in 1985 to 1986 and 1994 to 1995, there was a sharp and significant increase in BMI. These two points occurred after two major economic policy changes that increased the purchasing power of the population related to economics factors such as: reducing the level of social inequality, increased family income, poverty reduction, inflation control, and increased consumption of foods. The present study showed a sharp increase of obesity in the population of young men in Brazil on two occasions during this series (years 1985 to 1986 and 1994 to 19955), when a possible reduction in caloric expenditure and increased food consumption population were observed.
\end{abstract}

Key words: Temporal trends, body mass index, obesity, Brazil.

\section{INTRODUCTION}

Trends of increasing overweight and obesity are now well documented in both developed countries for example, United States (Komlos and Brabec, 2010; Burkhauser et al., 2009), France (de Saint Pol, 2009), Japan (Yoshiike et al., 2002) and developing countries for example, Brazil (Wang et al., 2002) and Mexico (Rivera et al., 2004) but few studies have used time series with more frequent data collection points on weight change, which would allow testing, whether specific points in time are associated with more substantial increases in the rates of overweight and obesity.

Economic development, modernization, and urbanization have been associated to obesity (Staudigel, 2011;

\footnotetext{
*Corresponding author. E-mail: cesarmarra@gmail.com.
}

Peracchi and Arcaleni, 2011). Economic factors such as greater purchasing power of poor families (Lignani et al., 2011), low food prices (Christian and Rashad, 2009; Rashad, 2006), technological modernization (Lakdawalla and Philipson, 2009), increased family income (Fowler et al., 2005) are associated with dietary patterns of populations, particularly in developing countries, resulting in increased obesity (Mendez and Popkin, 2004; Ulijaszek and Koziel, 2007).

Recent data from the Brazilian Institute of Geography and Statistics (IBGE, 2010) reported that overweight has been increasing steadily in adults since the mid-1970s and it is currently found in approximately half of all Brazilians. Data from enlisted men have been used to describe the prevalence of overweight in Israel (Gross et al., 2009) and the United States (Hsu et al., 2007). These data are usually collected annually therefore they are a 
good resource for testing temporal changes, mainly when measured by professionals.

The objectives of this study are: (1) To evaluate the temporal change in BMl of enlisted men in Brazil from 1980 to 2005; (2) to test for specific points in time that display greater variance and; (3) to further compare specific points in time in the BMI temporal evolution with economic changes in Brazil.

\section{METHODOLOGY}

\section{Study population}

The present study explores a temporal series of twenty-six national surveys of Brazilian men who enlisted between 1980 and 2005. Each survey comprises a 35 to $40 \%$ of all Brazilian men aged 18 years at the time of examination. The article 143 in the Constitution of the Federative Republic of Brazil (1998) provides that a one year military service is compulsory. Women and clergymen are exempted from compulsory military service. Weight and height were measured to the nearest $0.1 \mathrm{~kg}$ and $0.5 \mathrm{~cm}$, respectively using a scale with incorporated stadiometer $\left(\right.$ Filizola $\left.^{\circledR}\right)$. All measurements were performed by previously trained examiners. Participants were weighed and measured wearing light clothing and no shoes.

\section{Body mass index data analysis}

The Brazilian candidates for compulsory military service are representative of the male population in general thus allowing one to assess the increase in the prevalence of obesity during the period of analysis and identify periods of change. Prevalence of overweight and obese men was calculated with 95\% confidence intervals, and the BMI values were plotted to make a descriptive analysis of the time series. This analysis showed that the variance of the error term was not equal over time that is, heteroscedasticity. The cutoff points of the World Health Organization (WHO, 2007) were used to classify overweight (BMI $\geq 25 \mathrm{~kg} / \mathrm{m}^{2}$ and $<30 \mathrm{~kg} / \mathrm{m}^{2}$ ) and obese $\left(B M I \geq 30 \mathrm{~kg} / \mathrm{m}^{2}\right)$ men.

Heteroscedasticity in BMI time series was tested using Engle's Lagrange-multiplier (LM) test, and analyses were performed using the autoregressive conditional heteroscedasticity $(\mathrm{ARCH}(1))$ model (Engle, 1982; Bollerlev et al., 1994) with a level of significance set at $p<0.05$. For those points in time with higher oscillations of the mean of BMI (1985, 1994 and 2000), dummy variables were included under the assumption that the growth rate of mean BMI was not the same throughout the period.

When heteroscedasticity is present, the regression coefficients for an ordinary least squares regression (OLS) are unbiased, but the variance and confidence intervals estimated by conventional procedures will be too narrow, giving a false sense of precision. In this context, an ARCH model, introduced by Engle (1982), is an appropriate framework for analyzing the data. All analyses were performed using the STATA.

\section{Economic factors}

As possible explanations for these increases in mean BMI, changes in economic indicators were considered (Brazilian Institute of Geography and Statistics and Institute of Applied Economic Research). The economics factors which have been analyzed were: annual inflation rate, food production, poverty (\%), soft drinks consumption and average annual real income.

\section{Annual inflation rate}

The annual inflation rate was measured by the General Price Index, an index that attempts to reflect the monthly variations in prices (\%). The index calculates the price variations of agricultural raw materials and wholesale industrial and final goods and services for consumption. Annual inflation was measured by the average of the 12 months of the year (IPEA, 2010).

\section{Food production}

Food production was measured by indicators for aggregated products that represent the sectors that provide supplies directly to livestock or delivering the first industrial processing of goods resulting from activities in the primary sector. The series consists of products and aggregates defined class-based agribusiness industry $($ year $1989=100)(A B I A, 2010)$.

\section{Poverty}

Poverty was measured by the percentage (\%) of people in total population with per capita household income below poverty line. The poverty line is twice the extreme poverty line, an estimate of the value of a basic food basket with a minimum of calories needed to adequately sustain life, based on the recommendations of Food and Agriculture Organization and WHO (IPEA, 2009).

\section{Soft drink consumption}

The Soft drink consumption was measured by the annual wholesale value of soft drinks and juices in liters per year (I/y) (ABIR, 2009).

\section{Average annual income}

The series were calculated from all jobs of employed persons with employment income (IPEA, 2008). The annual income was measured by the average of the 12 months of the year and in national currency: Real $(R \$)$. The study was approved by the Research Ethics Committee of Rio de Janeiro State University, Institute of Social Medicine (protocol number 397523).

\section{RESULTS}

The study population of $11,090,230$ males showed an increase in mean BMl from $21.4 \mathrm{~kg} / \mathrm{m}^{2}$ in 1980 to 22.2 $\mathrm{kg} / \mathrm{m}^{2}$ in 2005 . The prevalence of overweight men changed from $4.5 \%$ in 1980 to $12.5 \%$ in 2005 (2.6 times larger). The prevalence of obesity increased from $0.5 \%$ in 1980 to $1.9 \%$ in 2005 , an increase of almost $300 \%$ during the period; although these values are still at low level in international comparison. Table 1 shows increasing variance of mean $\mathrm{BMI}$ over time, indicating heteroscedasticity.

The LM test of heteroscedasticity on BMI showed ap-value 
Table 1. Mean, standard deviation (SD) and variance of body mass index (BMI) and the prevalence of overweight and obesity (\%) and the 95\% confidence interval (Cl) in Brazilian enlisted men, 1980 to 2005.

\begin{tabular}{|c|c|c|c|c|c|c|c|c|c|}
\hline \multirow{3}{*}{$\begin{array}{l}\text { Year } \\
1980\end{array}$} & \multicolumn{3}{|c|}{ BMI $\left(\mathrm{kg} / \mathrm{m}^{2}\right)$} & \multirow{3}{*}{$\begin{array}{c}\text { Overweight (\%) } \\
4.51\end{array}$} & \multirow{2}{*}{\multicolumn{2}{|c|}{$95 \% \mathrm{Cl}$}} & \multirow{3}{*}{$\begin{array}{c}\text { Obesity (\%) } \\
0.37\end{array}$} & \multirow{2}{*}{\multicolumn{2}{|c|}{$95 \% \mathrm{Cl}$}} \\
\hline & \multirow{2}{*}{$\begin{array}{l}\text { Mean } \\
21.40\end{array}$} & \multirow{2}{*}{$\frac{S D}{2.11}$} & \multirow{2}{*}{$\begin{array}{c}\text { Variance } \\
4.45\end{array}$} & & & & & & \\
\hline & & & & & 4.43 & 4.57 & & 0.36 & 0.42 \\
\hline 1981 & 21.40 & 2.13 & 4.55 & 4.66 & 4.64 & 4.76 & 0.42 & 0.38 & 0.43 \\
\hline 1982 & 21.45 & 2.21 & 4.87 & 5.01 & 4.94 & 5.06 & 0.56 & 0.54 & 0.62 \\
\hline 1983 & 21.43 & 2.19 & 4.81 & 4.87 & 4.84 & 4.96 & 0.55 & 0.48 & 0.58 \\
\hline 1984 & 21.36 & 2.16 & 4.67 & 4.54 & 4.44 & 4.56 & 0.47 & 0.45 & 0.52 \\
\hline 1985 & 21.36 & 2.18 & 4.74 & 4.68 & 4.64 & 4.76 & 0.48 & 0.45 & 0.52 \\
\hline 1986 & 21.55 & 2.27 & 5.15 & 6.16 & 6.13 & 6.27 & 0.51 & 0.48 & 0.52 \\
\hline 1987 & 21.61 & 2.24 & 5.02 & 6.54 & 6.43 & 6.57 & 0.46 & 0.43 & 0.52 \\
\hline 1988 & 21.60 & 2.25 & 5.06 & 6.55 & 6.43 & 6.57 & 0.49 & 0.48 & 0.52 \\
\hline 1989 & 21.64 & 2.28 & 5.20 & 6.81 & 6.73 & 6.87 & 0.56 & 0.54 & 0.60 \\
\hline 1990 & 21.65 & 2.31 & 5.33 & 6.85 & 6.82 & 6.98 & 0.62 & 0.57 & 0.63 \\
\hline 1991 & 21.74 & 2.38 & 5.64 & 7.76 & 7.72 & 7.88 & 0.71 & 0.68 & 0.73 \\
\hline 1992 & 21.78 & 2.41 & 5.80 & 8.27 & 8.21 & 8.39 & 0.72 & 0.67 & 0.73 \\
\hline 1993 & 21.80 & 2.48 & 6.15 & 8.75 & 8.61 & 8.79 & 0.87 & 0.85 & 0.93 \\
\hline 1994 & 21.75 & 2.50 & 6.24 & 8.62 & 8.51 & 8.69 & 0.87 & 0.87 & 0.93 \\
\hline 1995 & 21.92 & 2.63 & 6.93 & 10.06 & 10.01 & 10.19 & 1.20 & 1.17 & 1.23 \\
\hline 1996 & 22.01 & 2.66 & 7.09 & 10.63 & 10.51 & 10.69 & 1.31 & 1.27 & 1.33 \\
\hline 1997 & 22.04 & 2.69 & 7.23 & 10.98 & 10.91 & 11.09 & 1.34 & 1.27 & 1.36 \\
\hline 1998 & 22.05 & 2.72 & 7.38 & 11.15 & 10.99 & 11.20 & 1.38 & 1.36 & 1.44 \\
\hline 1999 & 22.09 & 2.72 & 7.39 & 11.24 & 11.09 & 11.30 & 1.44 & 1.38 & 1.46 \\
\hline 2000 & 22.13 & 2.76 & 7.60 & 11.51 & 11.37 & 11.63 & 1.55 & 1.53 & 1.61 \\
\hline 2001 & 22.06 & 2.85 & 8.14 & 11.54 & 11.39 & 11.61 & 1.58 & 1.56 & 1.64 \\
\hline 2002 & 22.08 & 2.86 & 8.18 & 11.81 & 11.69 & 11.91 & 1.59 & 1.56 & 1.64 \\
\hline 2003 & 22.01 & 2.84 & 8.07 & 11.24 & 11.09 & 11.31 & 1.55 & 1.53 & 1.61 \\
\hline 2004 & 22.05 & 2.91 & 8.45 & 11.57 & 11.49 & 11.71 & 1.73 & 1.66 & 1.74 \\
\hline 2005 & 22.19 & 2.96 & 8.78 & 12.55 & 12.39 & 12.61 & 1.95 & 1.94 & 1.98 \\
\hline
\end{tabular}

of 0.0002 , rejecting the null hypothesis of no $\mathrm{ARCH}$ effects. The ARCH models were fitted including the dummy variables for the years 1985, 1994 and 2000 (the independent variables). Only 1985 and 1994 showed a statistically significant modification of the rate of change $(p<0.05)$. The year 2000 was not statistically significant $(p=0.54)$. Thus, the final model was ARCH (1) with two dummy variables (years 1985 and 1994). Data are shown in Figure 1 and the results of analysis are given in Table 2. From 1980 to 1985, there were no significant changes in mean BMI. From 1985 to 2005, BMI values increased.

In Table 2, the coefficients associated with the years 1985 and 1994 indicate the statistically significant changes. Thus, the constant represents the overall mean of $22.073 \mathrm{~kg} / \mathrm{m}^{2}$ in years 1985 and 1994 . The negative value $-0.232 \mathrm{~kg} / \mathrm{m}^{2}$ indicates a BMI smaller than mean BMI after 1985. The same apply for 1994 when BMI values after 1994 were $0.437 \mathrm{~kg} / \mathrm{m}^{2}$ greater. The bottom portion of Table 2 is related to the fit of the model. The coefficient $\mathrm{L} 1=0.49$ indicates that the variance of the current period error depends on information that is revealed in the preceding period. The years of change in BMI were accompanied by the usual changes in Brazilian's lifestyle (1985 to 1986 and 1994 to 1995) but by international comparison they are below average (Figure 1).

\section{DISCUSSION}

Non-genetic factors appear to have a major role in rapidly increasing rates of obesity (Ogden et al., 2007; Saarloos et al., 2009) but there is less consensus on the specific environmental factors that may contribute to such dramatic shifts (Jeffrey and Utter, 2003). Although young males are not the group with the greatest prevalence of overweight in Brazil, overweight changed from $4.5 \%$ in 1980 to $12.5 \%$ in 2005 , the prevalence in the overall population according to nationwide surveys in Brazil has increased substantially. Overweight and obesity combined 


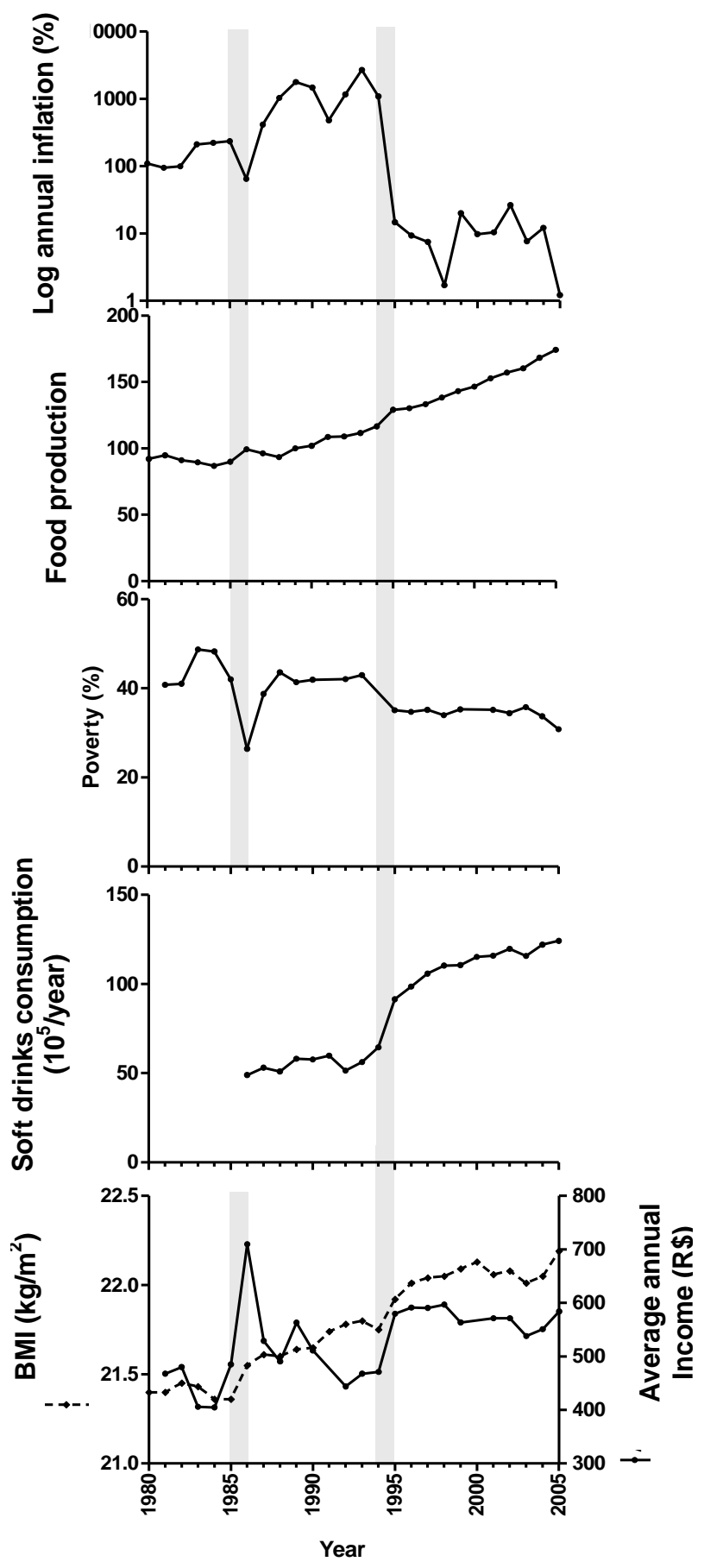

Figure 1. Log annual inflation (\%), food production, poverty $(\%)$, soft drink consumption $\left(10^{5}\right.$ liters/year, body mass index $\left(\mathrm{kg} / \mathrm{m}^{2}\right)$ and average annual income $(\mathrm{R} \$)$ in Brazil, 1980 to 2005. The shaded zones illustrate that the periods of economic growth (1985 to 1986 and 1994 to 1995) and are corresponding in time with increased sharp of BMI.

among adults has increased from 18.5 to $50 \%$ in the last 30 years indicating that the obesity epidemic is happen also in Brazil (IBGE, 2010).

The data of enlisted men provides a practical and large convenience sample of the Brazilian young male population and possibly reflects general population trends. We identified turning points in the BMI curve in 1985 and 1994 and also identified changes in the Brazilian economy of possible factors are corresponding in time with increased BMI. Beginning in 1985, a marked change in general consumption was noted with an increasing amount of available calories (Silveira and Almeida, 2008) and also the launching of many new food products (Mendonça and Anjos, 2004). Beginning in 1994, a trend was observed towards increased consumption of fast foods (Mendonça and Anjos, 2004) and soft drinks (ABIR, 2009).

The decline in inflation rate and consequent reduction in food prices, mainly for industrially-produced food products, was observed in both periods and many authors have concluded that low food prices induce people to consume more calories (Mitra, 2001; Cutler et al., 2003; Chou et al., 2004). Glanz et al. (1998) found that cost is one of the most important factors in food-purchasing decisions and that these trends toward increased consumption and reduced industrialized food prices (for example, soft drinks and vegetable oils) have also been observed in the past three decades in other developing countries (Popkin, 1993).

An increase in wages mainly among the poor (Lavinas, 2001; IBGE, 2007) and the reduction of inequality (Hoffman, 2002) were also a result of the 1994 real plan in Brazil, a major economic intervention by the government, which increased food consumption in res-taurants and fast food establishments (Mendonça and Anjos, 2004). Eating outside the home has been associated with obesity in studies conducted in the United States (Guthrie et al., 2002) and Europe (Orfanos et al., 2007) and in Brazil eating outside the home has been associated with obesity among men (Bezerra and Sichieri, 2009).

In the United States, increased rates of obesity have coincided with a large increase in average caloric intake between 1985 and 2000 when more fats were added to homemade foods and many processed foods (Chastenet, 2011) and in Brazil, an increase in processed foods and sodas has been well documented (Levy-Costa et al., 2005). Watching television has also received great attention for its contribution to a sedentary lifestyle (Finkeltein et al., 2005). Time spent on computers, video games and other electronic resources have increased substantially since the 1980's in Brazil. Furthermore, an increase in TV sales was observed in the period 1994 to 1995 (Mendonça and Anjos, 2004).

\section{Conclusion}

Finally, the results of this study show that between 1980 
Table 2. ARCH model for BMI. Brazilian enlisted men, 1980 to 2005.

\begin{tabular}{lcccc}
\hline Parameter & Coefficient & $\mathbf{P}>|\mathbf{z}|$ & \multicolumn{2}{c}{ 95\% Confidence interval } \\
\hline BMI $\left(\mathbf{k g} / \mathbf{m}^{\mathbf{2}}\right)$ & & & & \\
Year 1985 & -0.232 & 0.001 & -0.321 & -0.144 \\
Year 1994 & -0.437 & 0.001 & -0.555 & -0.319 \\
constant & 22.073 & 0.001 & 22.025 & 22.122 \\
& & & & \\
ARCH & & & & \\
L1 & 0.497 & 0.043 & 0.015 & 0.979 \\
constant & 0.003 & 0.020 & 0.000 & 0.005 \\
\hline
\end{tabular}

and 2005, we identified that two points of rate of change in BMI are corresponding in time with economic changes that altered Brazilians' lifestyles. Much has yet to be investigated on the influence of economic factors on the development of obesity and although time series studies are not considered the best framework for causal analysis, this methodology clearly allows the identification of major changes over time, as shown in our analyses. Because of their public health importance, trends in overweight and obesity need to be monitored continuously and factors associated with these trends studied, in order to develop sound health-policy strategies to improve health and prevent obesity.

\section{ACKNOWLEDGEMENTS}

The authors would like to thank the Brazilian Army for making the data available.

\section{REFERENCES}

ABIA (Brazilian Association of Food Industries) (2010). Departamento de Economia e Estatística. Série histórica. Pesquisa conjuntural. http://www.abia.org.br/economia.asp.

ABIR (Brazilian Association of Soft Drink and non Alcoholic Industries) (2009). Volume de consumo de refrigerantes de 1986 a 2008. http://www.abir.org.br.

Bezerra I, Sichieri R (2009). Eating out of home and obesity: a Brazilian nationwide survey. Public Health Nutr. 12:2037-2043.

Bollerlev T, Engle RF, Nelson DB (1994). ARCH models. In: Engle RF, McFadden DL (Eds), Handbook of Econometrics, Volume IV, Elsevier Science BV, North Holand. Chapter 49. [http://econ.duke.edu/ boller/econ.350/ben_hand_94].

Burkhauser RV, Cawley J, Schmeiser MD (2009). The timing of the rise in U.S. obesity varies with measure of fatness. Econ. Hum. Biol. 7(3):307-318.

Chastenet $H$ (2011). Economic factors affecting the increase in obesity in the United States: Differential response to price. A paper submitted to the Graduate Faculty of North Dakota State University of Agriculture and Applied Science. [http://www.ext.nodak.edu/ aedept/aemisc/deChastenet-Thesis-.pdf].

Chou SY, Grossman M, Saffer H (2004). An economic analysis of adult obesity: Results from the Behavioral Risk Factor Surveillance System. J. Health Econ. 23:565-87.
Christian T, Rashad I (2009). Trends in U.S. Food Prices, 1950-2007. Econ. Hum. Biol. 7:113-120.

Constitution of the Federative Republic of Brazil (1988). Brasília, DF: Senado Federal. Available http://bd.camara.gov.br/bd/handle/bdcamara/1344.

Cutler DM, Glaeser EL, Shapiro JM (2003). Why have Americans become more obese? J. Econ. Perspect. 17: 93-118.

de Saint Pol T (2009). Evolution of obesity by social status in France, 1981-2003. Econ. Hum. Biol. 7(3):398-404.

Engle RF (1982). Autoregressive conditional heteroscedasticity with estimates of the variance of United Kingdom inflation. Econometrica 50(4):987-1008.

Finkelstein E, Ruhm CJ, Kosa KM (2005). Economic Causes and Consequences of Obesity. Ann. Rev. Public Health 26:239-257.

Fowler SP, Williams K, Hunt KJ, Resendez RG, Hazuda HP, Stern MP (2005). Diet soft drink consumption is associated with increased incidence of overweight and obesity in the Santo Antonio heart study. ADA annual meeting,1058p.

Glanz K, Basil M, Maibach E, Goldberg J, Snyder D (1998). Why Americans eat what they do: Taste, nutrition, cost, convenience, and weight control concerns as influences on food consumption. J. Am. Diet Assoc. 98:1118-1126.

Gross R, Brammli-Greenberg S, Gordon B, Rabinowitz J, Afek A (2009). Population-based trends in male adolescent obesity in Israel 1967 - 2003. J. Adolesc. Health 44:195-198.

Guthrie JF, Lin B-H, Frazao E (2002). Role of food prepared away from home in the American diet, 1977-78 versus 1994-96: changes and consequences. J. Nutr. Educ. Behav. 34:140-150.

Hoffman R (2002). Distribuição da renda no Brasil no período 19922001. Economia e saúde. [http://www.eco.unicamp.br/docdownload/publicacoes/instituto/revista s/economia-e-sociedade/V11-F2-S19/02-Hoffmann.pdf].

Hsu LL, Nevin RL, Tobler SK, Rubertone MV (2007). Trends in overweight and obesity among 18-year-old applicants to the United States military, 1993-2006. J. Adolesc. Health 41: 610-612.

IBGE (Brazilian Institute of Geography and Statistics) (2007). A evolução do Salário Mínimo Real Médio entre 1980 e 2006. Ministério do Trabalho e Emprego. Brasília, Brazil, Ministério da Saúde. [http://www.ibge.org.br].

IBGE (Brazilian Institute of Geography and Statistics) (2010). Pesquisa de Orçamentos Familiares. Antropometria e análise do estado nutricional de crianças e adolescentes no Brasil 2008-2009. Brasília, Brazil, Ministério da Saúde. [http://www.ibge.gov.br].

IPEA (Institute of Applied Economic Research) (2008). Economic data. [http://www.ipeadata.org.br].

IPEA (Institute of Applied Economic Research) (2009). Pobreza eriqueza no Brasil metropolitano. Rio de Janeiro, Brazil. [http://www.ipeadata.org.br].

IPEA (Institute of Applied Economic Research) (2010). A Inflação no Brasil. Índice Gerais de Preços. Rio de Janeiro, Brazil. [ http://www.ipeadata.org.br] 
Jeffrey R, Utter J (2003). The changing environment and population obesity in the United States. Obes. Res. 11:12S-22S.

Komlos J, Brabec M (2010). The Trend of BMI Values of US Adults by Deciles, Birth Cohorts 1882-1986. Stratified by Gender and Ethnicity. National Bureau of Economic Research, Working Paper 16252.

Lignani JB, Sichieri R, Burlandy L, Salles-Costa R (2011). Changes in food consumption among the Programa Bolsa Família participant families in Brazil. Public Health Nutr. 14(5):785-92.

Lakdawalla D, Philipson T (2009). The growth of obesity and technological change. Econ. Hum. Biol. 7(3):283-293.

Lavinas L (2001). Acessibilidade alimentar e estabilização econômica no Brasil nos anos 90. [http://www.ipea.gov.br/pub/td/td0591.pdf]

Levy-Costa RB, Sichieri R, Pontes NS, Monteiro CA (2005). Disponibilidade domiciliar de alimentos no Brasil: distribuição e evolução (1974-2003). J. Public health 39(4):530-540.

Mendonça CP, Anjos LA (2004). Aspectos das práticas alimentares e da atividade física como determinantes do crescimento do sobrepeso/obesidade no Brasil. Cad. Saude Publica 20(3):698-709.

Mendez M, Popkin B (2004). Globalization, urbanization and nutritional change in the developing world. J. Agric. Dev. Econ. 1:220-241.

Mitra A (2001). Effects of physical attributes on the wages of males and females. Appl. Econ. Lett. 8:731-735.

Ogden CL, Yanovski SZ, Carroll MD, Flegal KM (2007). The epidemiology of obesity. Gastroenterology 132:2087-2102.

Orfanos P, Naska A, Trichopoulos D, Slimani N, Ferrari P, van Bakel M (2007). Eating out of home and its correlates in 10 European countries. The European Prospective Investigation into Cancer and Nutrition (EPIC) study. Public Health Nutr. 10:1515-1525.

Peracchi F, Arcaleni E (2011). Early-life environment, height and BMI of young adult males in Italy. Econ. Hum. Biol. 9:251-264.

Popkin BM (1993). Nutritional patterns and transitions. Popul. Dev. Rev. 19(1):138-157.
Rashad I (2006). Structural estimation of caloric intake, exercise, smoking, and obesity. Q. Rev. Econ. Finance 46:268-283.

Rivera JA, Barquera S, González-Cossío T, Olaiz G, Sepúlveda J (2004). Nutrition Transition in Mexico and in other Latin American countries. Nutr. Rev 62(7):149-157.

Saarloos D, Kim J-E, Timmermans H (2009). The built environment and health: Introducing individual space-time behavior. Int. J. Environ. Res. Pub. Health 6:1724-1743.

Silveira FG, Almeida MEK (2008). Fome, Produção Alimentar e Distribuição de Renda. [http://revistas.fee.tche.br/index.php/indicadores/article/viewFile/530/ 766].

Staudigel M (2011). How (much) do food prices contribute to obesity in Russia? Econ. Hum. Biol. 9:133-147.

Ulijaszek SJ, Koziel S (2007). Nutrition transition and dietary energy availability in Eastern Europe after the collapse of communism. Econ. Hum. Biol. 5: 359-369.

Wang Y, Monteiro C, Popkin BM (2002). Trends of obesity and underweight in older children and adolescents in the United States, Brazil, China, and Russia. Am. J. Clin. Nutr. 75:971-977

WHO (World Health Organization) (2007). The challenge of obesity in the WHO European Region and the strategies for response. Branca F, Nikogosian H and Lobstein T (eds.). WHO, Copenhagen, Denmark.

Yoshiike N, Seino F, Tajima S, Arai Y, Kawano M, Furuhata T, Inoune S (2002). Twenty-year changes in the prevalence of overweight in Japanese adults: The National Nutrition Survey 1976-1995. Obes. Rev. 3:183-190. 